\title{
Present Conditions of Occupational Health Services for Small-Scale Enterprises in Japan and Their Administrative Support
}

\author{
Toshiaki Higashi', Tetsuya Mizoue², Takashi Muto², \\ Yasushi FUKUWATARI ${ }^{3}$, Takesumi YOSHIMURA², Katsuya YAHATA', \\ and Seiji MACHIDA ${ }^{4}$ \\ ${ }^{1}$ Department of Work Systems and Health, Institute of Industrial Ecological Sciences, University of \\ Occupational and Environmental Health, Japan. Yahatanishi-ku, Kitakyushu 807, Japan \\ ${ }^{2}$ Department of Clinical Epidemiology, Institute of Industrial Ecological Sciences, University of \\ Occupational and Environmental Health, Japan. Yahatanishi-ku, Kitakyushu 807, Japan \\ ${ }^{3}$ Department of Public Health, School of Medicine, Juntendo University, Japan. \\ Bunkyo-ku, Tokyo 113, Japan \\ ${ }^{4}$ East Asia Multidisciplinary Team, ILO Regional Office for Asia and the Pacific, ILO. \\ Bangkok 10501, Thailand
}

Abstract: As of 1989, in Japan, around 29 million (58.3 percent) of the 49 million total labor population are working for small-scale enterprises (SSEs) where less than 50 workers are employed. This rate is higher than the average of about 40 percent in the OECD nations. It can not be denied that the occupational health service (OHS) for workers in SSEs is not adequate when compared with those for workers engaged in large enterprises. This can be seen in terms of occupational safety and health due to financial weakness of SSEs, and/or limitation of obligation provided for by the Law, e.g.. The appointment of an occupational health physician is not necessary in SSEs. The primary administrative authority in Japan, the Ministry of Labour, has been providing various subsidy programs for OHS in SSEs, including support for health examinations, health promotion and improvement of work conditions and environment. In 1993, the Ministry of Labour established both regional and prefectural occupational health centers to provide services for workers in SSEs. The prefectural occupational health centers also provide information and consultation regarding technical skills to OHPs.

Key words: occupational health service, small-scale enterprise, financial subsidy, Japan, occupational health center.

(Received 15 August 1994, accepted 27 Septenber 1994)

\section{Introduction}

As of 1989 in Japan, more than 40 million workers in a total labor 
population of 49 million are working for small and medium-scale enterprises where less than 300 workers are employed [1], and 58.3 percent of them are working for small-scale workplaces where less than 50 workers are employed. Here "enterprise" means a commercial organization and "workplace" means an enterprise, a local unit of an enterprise or an auxiliary controlled by such an enterprise, and regulations concerning the occupational hygiene and human resources for enterprises are mainly prescribed based on a workplace [2]. Although the percentage of workers who are engaged in small-scale enterprises is higher compared with that of an average of about 40 percent in the OECD nations, it can not be denied that occupational health services for workers in small-scale enterprises is inadequate when compared with those for workers of large enterprises because of the limitation of obligations provided for by the Industrial Safety and Health Law (hereinafter referred to as the "Law") [3].

The primary administrative authority of occupational health in Japan is the Ministry of Labour (hereinafter referred to as the "Ministry"). Dealing with this situation, the Ministry has implemented several measures for maintaining and promoting the workers' health. In this paper, the authors have reviewed the present situation of OHS for small-scale enterprises and the administrative support for them.

\section{Gurrent Condition of OHS in Japan}

Human resources for OHS mandated by the Law

According to the Law [4], a health supervisor (HS), who has a role similar to that of a health officer in the UK, should be appointed from among the workers who belong to the enterprises, and the number of HSs should be determined in accordance with the size of the workplace. The Law states that a HS shall be appointed for a workplace where 50 to 199 workers are always employed, two HSs for 200 to 499 workers, three HSs for 500 to 999 workers, four HSs for 1,000 to 1,999 workers, five HSs for 2,000 to 2,999 workers, and six HSs for more than 3,000 workers. With regard to the occupational health physician (OHP), one OHP or more shall be appointed in accordance with the size of the workplace as provided by the Law. The Law states that an OHP shall be appointed on a full-time basis for a workplace where not less than 50 workers are always employed, one OHP shall be appointed on a full-time basis exclusive to a single workplace where 1,000 workers or more are always employed or where 500 or more workers are always engaged in hazardous work, and two or more OHPs shall be appointed on a full-time basis exclusive to a workplace where the number of workers exceeds 3,000 


\section{Medical insurance system}

As for health insurance, the supplier varies with the type and size of the enterprise. The supplier for workers of large-scale enterprises is the health insurance society which is organized by each company or a group of member companies. The government organizes a supplier for workers of small and medium-scale enterprises, and the local authorities organize those for independent enterprises [5] (Table 1). In Japan, it is prescribed by law that all nationals must be insured. The government has adopted measures for the purpose of reconciling such differences in health insurance systems. Workmen's accident compensation insurance is administered solely by the government.

\section{Activities of $\mathrm{OHS}$}

The distribution of the Japanese labor population, classified by size, who received major OHS is shown in Table $2[6]$. There is an indication common to the items including regular medical examinations (RMEs), safety and health education, and measures for maintaining and improving a worker's health that as the size of the enterprise becomes smaller, the percentage of those who

Table 1. Outline of the medical insurance system and the number of people covered in 1990

\begin{tabular}{|c|c|c|c|c|}
\hline & & Insured persons & $\begin{array}{c}\text { The supplier } \\
\text { of insurance } \\
(1990)\end{array}$ & $\begin{array}{l}\text { (A) The insured persons } \\
\text { (B) Dependents } \\
\text { Total number }(\times \mathbf{1 0 , 0 0 0})\end{array}$ \\
\hline \multirow{2}{*}{$\begin{array}{l}\text { Health } \\
\text { Insurance }\end{array}$} & $\begin{array}{l}\text { Government-administered } \\
\text { health insurance }\end{array}$ & $\begin{array}{l}\text { Mainly salaried workers } \\
\text { at small and medium } \\
\text { enterprises }\end{array}$ & State & $\begin{aligned} & \text { (A) } 1,733 \\
& \text { (B) } 1,836 \\
& \text { Total } \mathbf{3 , 5 6 9}\end{aligned}$ \\
\hline & $\begin{array}{l}\text { The union-administered } \\
\text { health insurance }\end{array}$ & $\begin{array}{l}\text { Mainly salaried workers } \\
\text { at big enterprises }\end{array}$ & $\begin{array}{l}\text { Health Insurance } \\
\text { Society } \\
\qquad 1,818\end{array}$ & $\begin{array}{r}\text { (A) } 1,417 \\
\text { (B) } 1,729 \\
\text { Total } \mathbf{3 , 1 4 6}\end{array}$ \\
\hline \multicolumn{2}{|c|}{ Seamen's Insurance } & Seamen & State & $\begin{array}{r}\text { (A) } 14 \\
\text { (B) } 30 \\
\text { Total } 44 \\
\end{array}$ \\
\hline \multicolumn{2}{|c|}{ Mutual Aid Association } & $\begin{array}{l}\text { National public servants } \\
\text { Local public servants }\end{array}$ & $\begin{array}{l}\text { Mutual Aid } \\
\text { Association } \\
82\end{array}$ & $\begin{aligned} \text { (A) } 506 \\
\text { (B) } 699 \\
\text { Total } \mathbf{1 , 2 0 5}\end{aligned}$ \\
\hline \multirow{3}{*}{\multicolumn{2}{|c|}{ National Health Insurance }} & $\begin{array}{l}\text { Farmers, } \\
\text { Independent businessmen, }\end{array}$ & $\begin{array}{r}\text { Municipal } \\
3,262 \\
\end{array}$ & \multirow{3}{*}{$\begin{array}{l}\text { Municipal: } \\
\quad 3,973 \\
\text { Natinal Health } \\
\text { Insurance Union: } \\
406 \\
\text { Total } \mathbf{4 , 3 7 9}\end{array}$} \\
\hline & & etc & Union & \\
\hline & & $\begin{array}{l}\text { The retired that had been } \\
\text { insured by employers }\end{array}$ & $\begin{array}{r}166 \\
\text { Municipal } \\
3,262\end{array}$ & \\
\hline \multicolumn{2}{|c|}{ Senior Citizens Insurance } & $\begin{array}{l}\text { Persons over } 70 \\
\text { Bedridden persons over } 65\end{array}$ & $\begin{array}{l}\text { (Main supplier) } \\
\text { Municipal Mayors }\end{array}$ & 956 \\
\hline
\end{tabular}

From: Health Insurance Bureau of the Ministry of Health and Welfare, 1991 [5] 
Table 2. Implementation ratio of Industrial safety and health measures in small and medium-scale enterprises

\begin{tabular}{lccccc}
\hline & Total & $\begin{array}{l}\text { Regular } \\
\text { medical } \\
\text { Cxamination }\end{array}$ & Counseling & $\begin{array}{l}\text { Safety } \\
\text { and health } \\
\text { education }\end{array}$ & $\begin{array}{l}\text { Measures for } \\
\text { maintaining and } \\
\text { improving health }\end{array}$ \\
\hline Size & $100.0(3052)$ & 80.9 & 16.4 & 37.6 & 33.4 \\
& $100.0(977)$ & 61.2 & 15.9 & 17.8 & 16.8 \\
$20-19$ & $100.0(539)$ & 80.1 & 16.7 & 29.7 & 27.8 \\
$30-49$ & $100.0(749)$ & 89.1 & 15.8 & 37.5 & 35.4 \\
$50-99$ & $100.0(409)$ & 97.6 & 16.6 & 61.1 & 53.3 \\
\multicolumn{10}{c}{$100-299$} & $100.0(378)$ & 98.4 & 18.3 & 75.1 & 58.5 \\
\hline Manufacturing industry & $100.0(1576)$ & 92.3 & 15.4 & 52.9 & 44.9 \\
Wholesale Industry & $100.0(565)$ & 78.2 & 12.9 & 20.0 & 24.6 \\
Retailing & $100.0(404)$ & 56.9 & 19.6 & 19.1 & 18.8 \\
Service industry & $100.0(507)$ & 67.3 & 20.9 & 24.7 & 18.9 \\
\hline
\end{tabular}

From: "Study on the actual situation of working environment and future countermeasures." by the Japan Small and Medium Scale Business Association [6].

Nota: Questions are about implementation of measures including provision of welfare and health care facilities. Items in this Table were chosen from more than 30 items which are focused on implementation of the industrial health meaurements. Implementation ratios are not as low as other welfare measurements.

receive medical services drops. Examination items for the periodical health examination required by the Law are: (1) medical and work history, (2) subjective and objective symptoms, (3) height, weight, eyesight and hearing, (4) thoracic X-ray examination and sputum examination, (5) blood pressure, (6) anemia, (7) liver function, (8) lipid level in blood, (9) urinalysis, and (10) electrocardiogram. For workers aged under 34 or 36 to 39, items (7) to (10) can be omitted if it is considered unnecessary by the OHP.

The difference in coverage of OHS according to the size of enterprises is significant in safety and health education and measures for maintaining and improving health. There is also an indication, as shown in Table 2, that the implementation percentage of RMEs in the manufacturing industry is lower than other industries. Over $80 \%$ of enterprises where 20 or more workers are employed are receiving RMEs, and the proportion of workers receiving OHSs is increasing annually. The institutions that provide RMEs vary according to the size of the enterprises (Table 3). It is often the case with large-scale enterprises that RMEs are conducted on workers by their own OHP (or one under contract) utilizing their own medical staff and facilities or by linking up with outside medical examination institutions. In many SSEs where less than 1,000 workers are employed, the tendency to utilize medical examination institutions is increasing. The percentage of enterprises where RMEs are performed by OHPs is approaching 59\% in large-scale enterprises, whereas that of enterprises which obtain RME services at private hospitals, clinics, and 
Table 3. Institutions providing regular medical examination services (Classified by sizes)

\begin{tabular}{|c|c|c|c|c|c|c|c|}
\hline Classification & Total & $\begin{array}{l}\text { Occupational } \\
\text { physician of a } \\
\text { workplace }\end{array}$ & $\begin{array}{l}\text { Medical } \\
\text { examination } \\
\text { institutions }\end{array}$ & $\begin{array}{l}\text { Public hospitals } \\
\text { and } \\
\text { medical centers }\end{array}$ & $\begin{array}{l}\text { Private } \\
\text { hospitals and } \\
\text { clinics }\end{array}$ & $\begin{array}{l}\text { Public health } \\
\text { centers }\end{array}$ & Others \\
\hline All Sizes & 100.0 & 10.4 & 47.0 & 4.6 & 21.7 & 8.0 & 6.6 \\
\hline $\begin{array}{c}\text { more than } \\
5,000\end{array}$ & 100.0 & 90.2 & 7.7 & - & 2.1 & - & - \\
\hline $1,000-4,999$ & 100.0 & 58.8 & 31.0 & 0.8 & 6.7 & - & 2.7 \\
\hline $300-999$ & 100.0 & 34.9 & 43.2 & 3.1 & 12.5 & 0.7 & 5.4 \\
\hline $100-299$ & 100.0 & 25.9 & 46.6 & 3.1 & 15.5 & 2.9 & 5.8 \\
\hline $30-99$ & 100.0 & 14.4 & 46.0 & 4.1 & 21.1 & 6.0 & 8.3 \\
\hline $10-29$ & 100.0 & 7.1 & 47.6 & 5.0 & 22.7 & 9.4 & 6.0 \\
\hline
\end{tabular}

From : "Research on conditions of small and medium-scale industry workers." by the Ministry of Labour (1987) [7].

Note: Items in this table were chosen from the ones concerning the implementation conditions of the Safety and Health Management.

public health centers are increasing as their size becomes smaller [7].

The following is a digest of the problems from the financial and managerial aspects in promoting OHSs in SSEs. We consider many of them to be common to other countries as well [1]:

(1) weaker economic basis,

(2) low implementation rate of general medical examinations, examinations for adult diseases, and programs for mental health,

(3) the low appointment rate of OHPs,

(5) weaker trade unions,

(6) lower interest in occupational health on the part of both management and labor.

The following are the factors that worsen the quality of services in SSEs [8 -9] : (1) some OHP's lack of adequate training in occupational health, (2) clinical treatment or disease oriented stance of OHP, and (3) excessive work load of part-time OHPs.

\section{OHS Promoting System For SSEs in Japan}

The development of the OHS in Japan has been mostly fostered by the Prefectural Labour Standards Offices and Labour Standards Inspection Office of the Ministry who provide SSEs with necessary guidance, and also by the Japan Industrial Safety and Health Association (JISHA), established as an affiliated organization. In this section, we will focus on a subsidy system and a newly introduced support system in terms of human resources for the purpose of achieving appropriate and effective implementation of measures pertaining to industrial safety and health, including OHSs in SSEs. 


\section{Subsidy Program [10]}

To deal with the financial weakness in promoting OHS in SSEs, the Ministry has provided various subsidy programs for OHS related activities.

Table 4. Outline of the joint safety and health improvement project of small and medium-scale enterprises

\begin{tabular}{|c|c|c|}
\hline Target Project & Target Expense & Target Expense Items \\
\hline $\begin{array}{l}\text { 1. Steering committee activities, } \\
\text { such as settling on safety and } \\
\text { health annual project plans }\end{array}$ & $\begin{array}{l}\text { Expenses required in case of receiving guidance from } \\
\text { experts at the steering committee. }\end{array}$ & $\begin{array}{l}\text { Honorariums } \\
\text { Travel expenses } \\
\text { Liaison coordination expenses }\end{array}$ \\
\hline $\begin{array}{l}\text { 2. Safety and health education. } \\
\text { etc. } \\
\text { (1) Leader training }\end{array}$ & $\begin{array}{l}\text { 1) Expenses required for training safety and health leaders } \\
\text { in small and medium-sized enterprises. } \\
\text { 2) Expenses required for training educational instructors } \\
\text { of foremen education, etc. } \\
\text { a) Instructor training course (For those in charge of } \\
\text { education of foremen, etc.). } \\
\text { b) Instructor training course (For those in charge of } \\
\text { special education, etc.). }\end{array}$ & $\begin{array}{l}\text { Participation fees } \\
\text { Travel expenses }\end{array}$ \\
\hline $\begin{array}{l}\text { (2) Intra-group safety and } \\
\text { health education }\end{array}$ & $\begin{array}{l}\text { 1) Expenses required to carry out intra-group safety and } \\
\text { health seminars for management leaders. }\end{array}$ & $\begin{array}{l}\text { Honorariums } \\
\text { Travel expenses } \\
\text { Meeting place rental fees }\end{array}$ \\
\hline & $\begin{array}{l}\text { 2) Expenses required to carry out education, etc. of } \\
\text { foremen, etc. }\end{array}$ & Meeting place rental fees \\
\hline (3) Intra-group courses & $\begin{array}{l}\text { 1) Expenses required to hold workplace environment } \\
\text { improvement courses } \\
\text { 2) Expenses required to hold health education courses. }\end{array}$ & $\begin{array}{l}\text { Honorariums } \\
\text { Travel expenses } \\
\text { Meeting place rental fees }\end{array}$ \\
\hline $\begin{array}{l}\text { (4) Safety and health impro- } \\
\text { vement study meetings, } \\
\text { etc. }\end{array}$ & $\begin{array}{l}\text { Expenses required to carry out safety and health } \\
\text { improvement study meetings etc. }\end{array}$ & $\begin{array}{l}\text { Honorariums } \\
\text { Travel expenses }\end{array}$ \\
\hline $\begin{array}{l}\text { (5) National safety and health } \\
\text { convention }\end{array}$ & $\begin{array}{l}\text { Expenses required to participate in the national safety and } \\
\text { health convention. }\end{array}$ & $\begin{array}{l}\text { Travel expenses } \\
\text { Participation fees }\end{array}$ \\
\hline $\begin{array}{l}\text { 3. Safety and health consulta- } \\
\text { tion }\end{array}$ & $\begin{array}{l}\text { Expenses required for carrying out mutual safety and } \\
\text { health patrol, and for individual safety and health } \\
\text { consultations based on the results of patrol, etc. }\end{array}$ & $\begin{array}{l}\text { The following expenses for } \\
\text { individual safety and health } \\
\text { consultations: } \\
\text { Honorariums } \\
\text { Travel expenses }\end{array}$ \\
\hline 4. Medical examination & $\begin{array}{l}\text { Expenses required for carrying out the following legal } \\
\text { special medical examinations. } \\
\text { 1) Medical examination stipulated in Article } 29 \text { of the } \\
\text { Ordinance on the Prevention of Organic Solvent } \\
\text { Poisoning. } \\
\text { 2) Medical examination stipulated in Article } 53 \text { of the } \\
\text { Ordinance on the Prevention of Lead Poisoning. } \\
\text { 3) Medical examination stipulated in Article } 22 \text { of the } \\
\text { Ordinance on the Prevention of Tetra Alkyl Lead } \\
\text { Poisoning. } \\
\text { 4) Medical examination stipulated in Article } 39 \text { of the } \\
\text { Ordinance on the Provision of Hazards due to specified } \\
\text { chemical substances, etc. } \\
\text { 5) Medical examination stipulated in Article } 38 \text { of the } \\
\text { Ordinance on Safety and Health of Work under High } \\
\text { Pressure. } \\
\text { 6) Medical examination stipulated in Article } 56 \text { of the } \\
\text { Ordinance on the Prevention of Ionizing Radiation } \\
\text { Hazards. } \\
\text { 7) Medical examination (dentistry) stipulated in Article } 48 \\
\text { of the Ordinance on Industrial Safety and Health. } \\
\text { 8) Medical examination stipulated in Articles } 7 \text { and } 8 \text { of } \\
\text { the Pneumoconiosis Law }\end{array}$ & Medical examination fees \\
\hline
\end{tabular}


5. Work environment measurement

6. Special voluntary inspections

7. Follow-up measures for medical examination and health consultations
Expenses required for carrying out legally required work environment measurement of the following designated workshops.

1) Workshops described in Item 1 , Article 21 , of the Enforcement Order of the Industrial Safety and Health Law (dust).

2) Workshops described in Item 2, Article 53, of the Ordinance on the Prevention of Ionizing radiation Hazards among those stipulated by Item 6, Article 21 of the Enforcement Order of the Industrial Safety and Health Law (radioactive substances).

3) Workshops described in Item 7, Article 21, of the Enforcement Order of the Industrial Safety and Health Law (specified chemical substances).

4) Workshops described in Item 8, Article 26, of the Enforcement Order of the Industrial Safety and Health Law (lead).

5) Workshops described in Item 10, Article 21, of the Enforsement Order of the Industrial Safety and Health Law (organic solvents).

Expenses required for carrying out legally required special voluntary inspections of the following machines, etc.

1) Machines, etc., described in Item 12, Article 13, of the Enforcement Order of the Industrial Safety and Health Law (power press machines).

2) Machines, etc., described in Item 20, Article 13, of the Enforcement Order of the Industrial Safety and Health Law (forklifts).

3) Machines, etc., described in Item 21, Article 13, of the Enforcement Order of the Industrial Safety and Health Law (vehicle-type construction machines).

1) Expenses required for guidance concerning follow-up measures for health checkups.

2) Expenses required for carrying out health consultations.
Work environment measurement expenses

Special voluntary inspection expenses

Honorariums

Travel expenses

Besides the financial support, there are other programs which will help raise employers' concern for OHS and encourage them to learn how to deal with the matters through the process of obtaining assistance. A summary of eligible enterprises and the period of assistance are as follows (Table 4). Aid-target employer groups shall be groups of small and medium-scale employers (employers who are legal entities with a capital or total investment not exceeding $¥ 100$ million or whose regular workers are not more than 300 ) who satisfy the following requirements and are designated by the chief of the Prefectural Labour Standards Bureau which has jurisdiction over such groups (hereinafter called "designated groups").

1. Organized by area, business type, etc.

2. Consisting of small and medium-scale employers involved in dangerous or harmful work.

3. Having installed a safety and health council of management leaders.

4. Having set up a steering committee and a secretariat in charge of project planning, drafting and operations. 
5. Having adopted rules concerning the operations of the group.

6. The period of assistance by the government for the designated groups shall be limited to three years.

Major measures for the improvement of OHS in small-scale enterprises are shown in Table 4. The outline of the subsidy can be summarized as follows:

1. Subsidy for occupational health activities carried out in cooperation with several small-scale enterprises (activities such as health education, medical examinations and work environment measures.

2. Funds for the improvement of the work environment in small-scale enterprises.

3. Subsidy for measures to preserve and improve workers' health, called Total Health Promotion Plan (THP).

THP was given form when the Law was revised in 1988. For the implementation of the activities such as health measurements, provision of facilities for athletic activities, psychological consultation, nutritional instruction and health instruction, the government bear $2 / 3$ of the total expenses limited to 15 million yen for a maximum of three years, and also $1 / 2$ of the total expenses needed to carry out the training and education courses. With respect to the above mentioned subsidy, the enterprise or the workplace concerned can obtain a subsidy as a unit on condition that the subsidy shall be given in conjunction with an authorized organization.

There is also a subsidy program for the installment of health measurement equipment and training machines with the government bearing $1 / 3$ of the total expenses limited to 20 million yen per organization. These supportive measures have contributed to an increase in the number of workers who receive services and, consequently shortened the period that workers are unable to work due to injury and disease received in the workplace.

\section{Grant Amounts, Etc.}

(1) For projects in items $1-3$ and item 7 in Table 4 , the limit is $1 / 2$ of the expenses.

(2) The grant amount for costs required for health checkups shall be a fixed amount per person for each kind of health checkup (itemization omitted).

(3) The amount of grants for costs required for work environment measurements and special individual inspections is $1 / 2$ of the said costs per workplace, and a limit per workplace shall be set.

(4) The limit of the legal amount of grants for a group shall be 4 million yen, and the amount and duration of grants are varied according to the scale of the group, project contents, etc. However, aid will be extended within the range of up to 5 million yen for a group for which the aid is 
considered necessary for securing the effective implementation of the project.

\section{Regional Occupational Health Center $(\mathrm{OHC})$ [10]}

Due to their financial weakness, small-scale enterprises where less than 50 workers are always employed have difficulties in providing necessary services for workers such as regular health guidance and consultation by their own $\operatorname{OHP}(\mathrm{s})$. Consequently, the Ministry has established regional occupational health centers (OHCs) to meet these needs. Forty-seven centers have become available since the fiscal year 1993. The area covered by the centers is consistent with the Labour Standards Inspection Office. OHGs are established by district and municipal medical associations as required by the Prefectural Labour Standards Office. Plans for 347 centers are being drawn up at the present time.

\section{Activities of $\mathrm{OHC}$}

1. Health Care Consultation Service

Physicians and/or occupational health nurses provide health care consultation at the request of an employer or an employee of SSEs on prevention of diseases, methods of health promotion and so on once a week at a convenient location for the clients.

\section{Individual Visits}

The service includes provision for occupational health care guidance by worksite visits: (i) Eligible workplace; it shall be, in principle, a workplace where less than 50 are always employed, a workplace which has requested a visit, and a workplace that must be registered with OHC, (ii) Activities; doctors will visit workplaces individually, giving necessary instructions and advice on health administration based on the results of medical examinations. Doctors also examine workplaces, giving advice on improvement where necessary and to give counsel to workers based on the results of the medical examinations. Activities also include providing information on qualified OHPs, industrial health consultants, medical institutions, and occupational health institutions.

\section{Prefectural Occupational Health Promotion Center (OHPC)}

The primary objective of a prefectural occupational health promotion center is to provide consultation and information on the technical skills and know-how needed to make the activities of the OHP and OHC smooth and to support OHP training programs by the prefectural medical associations. The relationship between the institutions and channels for various OHS is shown in Fig. 1. Activities are as follows: (1) providing support to OHGs, (2) 


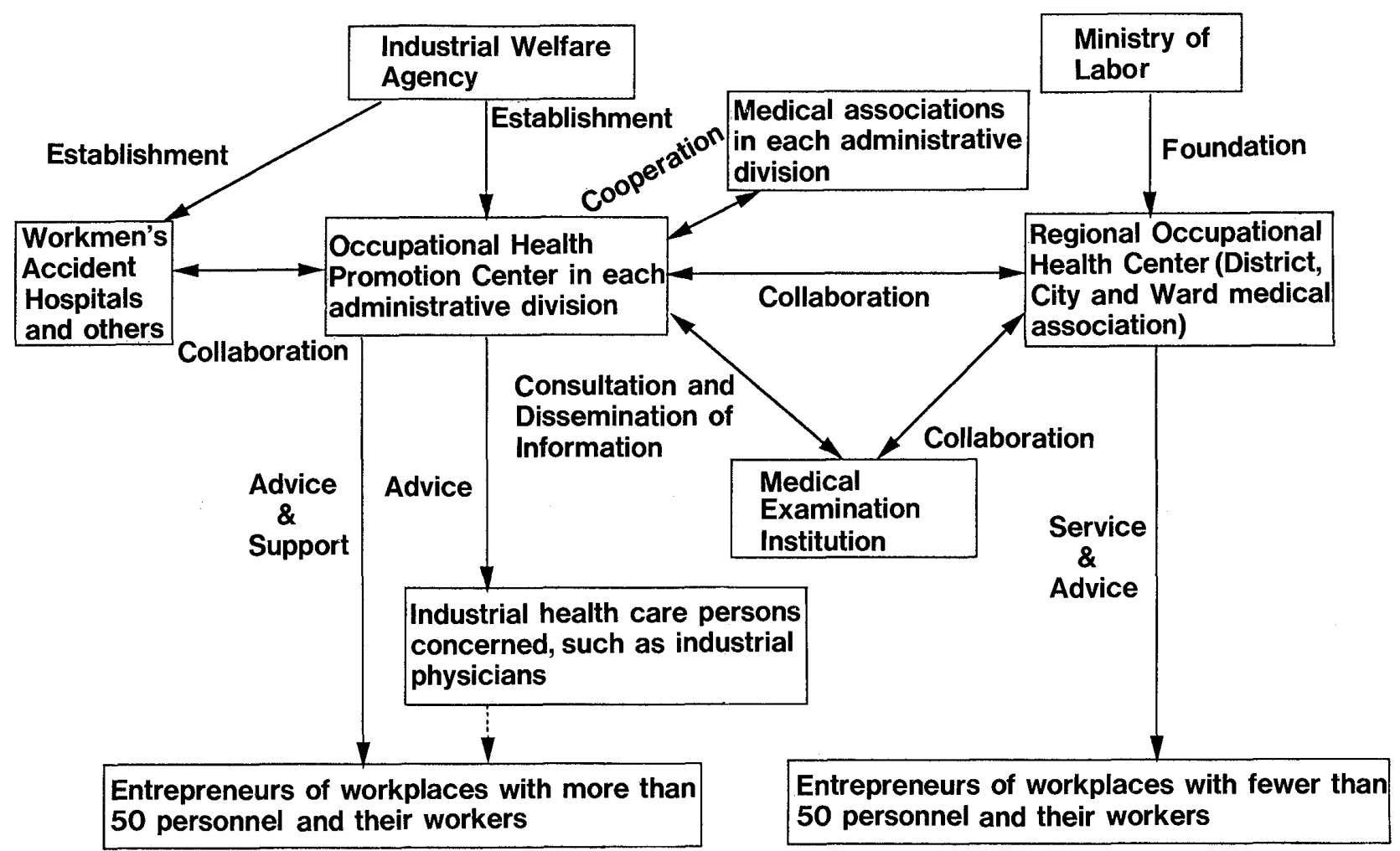

From: General Guidebook on Industrial Health, 1994 [10]

Fig. 1 The outline of the relationship of occupational health centers and other existiog organizations.

providing technical consultation on OHP, (3) collecting and providing information on occupational health, (4) compiling a data bank on occupational health.

Although the value of $\mathrm{OHG}$ and OHPG activities remains to be proven, much is expected of them as the core of the various channels for OHS.

This paper is a part of my presentation at the International Task Group Meeting on Health Protection and Health Promotion of Workers in Small-Scale Industries (Joint ILO/WHO) held in Bangkok, Thailand, January 1 to 3 in 1993.

\section{Acknowledgment}

This paper has been improved by the comments of Mr. Odera, the section chief of the Fukuoka Labour Standard Bureau. I should like to thank Mrs. Yasuko Nogami for her assistance in preparing the manuscript. 


\section{References}

1. Statistics Bureau, Management and Coordination Agency, Japan (1986): Statistic Survey of Workplaces. Statistics Bureau. Management and Coordination Agency, Japan, Tokyo pp 45-72 (in Japanese)

2. Statistics Bureau, Management and Coordination Agency, Japan (ed.) (1989): Japan Statistical Yearbook 1989. Statistics Bureau Management and Coordination Agency, Japan, Tokyo pp $49-80$

3. Takahashi K \& Okubo T (1994): Current Status of Ocupational Health in Japan. Occup Med 4: $66-69$

4. Japan Industrial Safety and Health Association (1991): Industrial Safety and Health Law and Related Legislation of Japan. Tokyo: Daiichi Houki Publishers, Tokyo pp 42-64

5. Health Insurance Bureau of the Ministry of Health and Welfare (1991): Annual Report on Health Insurance. Ministry of Health and Welfare, 1991 pp 18-34 (in Japanese)

6. Japan Small and Medium Scale Business Association (1991): Study on the actual situation of working environment and future countermeasures. Japan Small and Medium Scale Business Association, Tokyo pp 13-40 (in Japanese)

7. Ministry of Labour (1987): Research on conditions of small and medium scale industry workers. Ministry of Labour, Tokyo pp 34-52 (in Japanese)

8. Okubo T (1990): Problems in the current education and training system for occupational health physicians in Japan and strategies to solve them. UOEH 12: 269-282 (in Japanese with English abstract)

9. Takahashi K \& Okubo T (1990): Occupational physicians in Japan, their situation, number, task and system. Igaku no Ayumi 153: 434 (in Japanese)

10. Labour Standard Bureau in Ministry of Labour, Japan (1994): General Guidebook on Industrial Health. Japanese Industrial Safety and Health Association, Tokyo pp 43-190 (in Japanese) 
日本における中小企業への産業保健活動助成制度と意義

東 敏昭 ${ }^{1}$, 溝上 哲也 ${ }^{2}$, 武藤 孝司 ${ }^{3}$, 福渡 靖 ${ }^{3}$

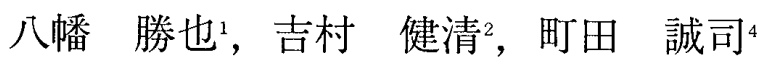

産業医科大学産業生態科学研究所 作業病態学教室,

2産業医科大学産業生態科学研究所 臨床疫学教室,

3順天堂大学医学部公衆衛生学教室,

4国際労働機関アジア太平洋事務局

要 旨： 1989 年現在，日本の全労働者人口約 4,900 万人の内，中小企業に従事する人口は 2,900 万人で $58.3 \%$ を占め，この割合は OECD 加盟諸国の平均 $40 \%$ を，大きく上 回る。一方，日本に扔ける産業保健に関わる制度は，産業医，衛生管理者などの産 業保健従事者の契的・雇用を始めとして，事業所の規模に基づき規定されている. 経済上および人材上の問題から，こうした小規模事業所に従事する集団は，大規模 事業所に従事する集団に比べ，相対的に産業保健サービスを受けにくい，労働省お よび関連機関は，対策として中小企業に対し産業保健サービス実施に際しての助成 制度を設けている。また，地域産業保健センターの設置による具体的サービスの推 進が試みられている，日本における保険，産業保健+ービスならびに中小企業にお ける問題を整理し，助成制度の概要，意義および運用について概説した。

J UOEH（産業医大誌）16（4）：309－320 (1994) 